\title{
Mirid feeding preference as influenced by light and temperature mediated changes in plant nutrient concentration in cocoa
}

Article

Accepted Version

Awudzi, G. K., Hadley, P., Hatcher, P. E. and Daymond, A. J. (2020) Mirid feeding preference as influenced by light and temperature mediated changes in plant nutrient concentration in cocoa. Annals of Applied Biology, 177 (3). pp. 395-403. ISSN 0003-4746 doi: https://doi.org/10.1111/aab.12636 Available at https://centaur.reading.ac.uk/92391/

It is advisable to refer to the publisher's version if you intend to cite from the work. See Guidance on citing.

To link to this article DOI: http://dx.doi.org/10.1111/aab.12636

Publisher: Wiley

All outputs in CentAUR are protected by Intellectual Property Rights law, including copyright law. Copyright and IPR is retained by the creators or other copyright holders. Terms and conditions for use of this material are defined in the End User Agreement.

www.reading.ac.uk/centaur 
Central Archive at the University of Reading

Reading's research outputs online 
1 Short running page heading: Mirid feeding preference on cocoa

2 Title: Mirid feeding preference as influenced by light and temperature mediated changes in

3 plant nutrient concentration in cocoa

4

$5 \quad{ }^{1}$ G.K. Awudzi*, ${ }^{2}$ P. Hadley, ${ }^{3}$ P.E. Hatcher, ${ }^{2}$ A.J. Daymond.

$6{ }^{1}$ Cocoa Research Institute of Ghana (CRIG), Box 8, New Tafo-Akim, Ghana. ${ }^{2}$ School of 7 Agriculture Policy and Development, University of Reading, Whiteknights, Reading, RG6 8 6AR, UK. ${ }^{3}$ School of Biological Sciences, University of Reading, Whiteknights, Reading, 9 RG6 6AS.

10 


\section{Abstract}

2 Cocoa mirids are the most important insect pests of cocoa in West Africa. This study 3 investigated the effect of environmental parameters that are modulated by overhead shade, 4 i.e. light intensity and temperature, on nutrient and phenolic concentrations in cocoa and their subsequent effect on mirid feeding. Eight-month-old cocoa seedlings were maintained for 50

6 days in two growth chambers set to day temperatures of $25^{\circ} \mathrm{C}$ or $30^{\circ} \mathrm{C}$. Each chamber had 7 sections with different light intensities (541, 365 and $181 \mu$ molm $^{-2} \mathrm{~s}^{-1}$ PAR). For the field 8 studies at Akim-Tafo in Ghana, eight-month-old plants of three cocoa clones were subjected 9 to shaded $\left(\mathrm{PAR}=180 \mu \mathrm{mol} \mathrm{m} \mathrm{m}^{-2} \mathrm{~s}^{-1}\right.$, between 11:00 and 12:00) and unshaded $(\mathrm{PAR}=1767$

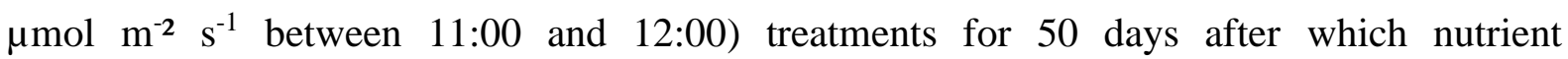
measurements and mirid choice tests were carried out. No significant effect of environment was observed on the phenolic concentration of stems under controlled environment chamber conditions. However, in the field, the phenolic concentration of stems was significantly greater for unshaded compared with shaded plants $(\mathrm{P}=0.04)$. Under controlled conditions, the leaf nitrogen concentration increased slightly with light intensity $(\mathrm{P}=0.003)$. The same trend was seen in stems but only at $30^{\circ} \mathrm{C}$. In the field, the impact of overhead shade on nitrogen varied between cocoa clones. The concentration of carbohydrates in both leaves and stems in the field was higher under unshaded conditions. When subjected to feeding tests, stems from unshaded cocoa had significantly more mirid feeding lesions $(\mathrm{P}=0.003)$ after 24 hours exposure to mirids compared to shaded cocoa. Mirid feeding therefore appears not to be deterred by the higher phenolic levels but rather there was a preference for cocoa tissue grown under unshaded conditions. These findings highlight the need to consider the growing environment of cocoa clones when screening for varieties with resistance to mirids.

Key words: cocoa, mirids, phenolics, plant nutrient, choice-test 


\section{$1 \quad 1.0 \quad$ Introduction}

2 Plants have evolved mechanisms over time to reduce insect feeding. Many plant secondary 3 metabolites are known to affect the feeding, growth and oviposition of insects (Halkier and

4 Du, 1997, Ossipov et al., 2001, Lattanzio et al., 2009). Such plant defence compounds 5 include proteinase inhibitors, which inhibit digestion of proteins in insects thereby causing 6 retarded growth and may eventually result in insect mortalities due to starvation (Stotz et al., 7 1999). As a group, the mirid species, Sahlbergella singularis Haglund and Distantiella 8 theobroma (Distant) (both Hemiptera: Miridae), are the most important insect pests on cocoa 9 (Theobroma cacao) in West Africa. Since plant phenolics and nutrients influence insect herbivory in a number of plant species (Dudt and Shure, 1994, Duffey and Stout, 1996,

11 Lattanzio et al., 2009), understanding the effects of environmental factors on plant nutrient concentration and plant defence compounds could aid mirid management on cocoa farms.

Campbell (1984) reported that knowledge of mirid nutrient requirements and defence compounds produced by cocoa against mirids is limited and this still remains the case today. Specifically, there is little information on the relationship between soluble carbohydrates in tissues and mirid feeding or the extent to which phenolics might deter feeding. On the other hand, nitrogen is suggested to be a limiting factor as feeding by mirids on cocoa tissue with a high nitrogen concentration has been associated with an increase in weight and overall growth of mirids as compared with mirids on nitrogen poor diets (Entwistle, 1972). Anikwe (2010) also showed that Sahlbergella singularis preferred cocoa pods that had high protein concentration. This might explain, in part, why fertilizer application generally has been associated with an increase in insect feeding (White, 1984, Thompson and Hagen, 1999, Lee et al., 2003) since nitrogen concentration would be expected to be higher in the leaves, chupons and young unhardened stems making them a preferred choice over food sources with a lower nitrogen concentration (Altieri and Nicholls, 2003).

Mirids are known to prefer unshaded areas of cocoa farms, where they create extensive damage referred to as pockets (Padi and Owusu, 1998, Bigger, 1981, Entwistle, 1985, Awudzi et al., 2009, Babin et al., 2010). High solar radiation in unshaded areas of cocoa farms or portions with a break in the shade canopy enhances photosynthetic rate and vegetative growth of the cocoa trees (Bos et al., 2007, Babin et al., 2010). These new shoots provide feeding and breeding sites which sustain mirid growth and development. The quality and quantity of light has also been reported to affect nutrient concentrations in plant tissues, 
1 which has a consequent influence on insect feeding (Bryant et al., 1983, Dudt and Shure, 2 1994). However, the extent to which environmentally induced changes in cocoa tissue 3 nutrient concentrations and defence compounds might impact on mirid feeding is not known.

4 Here, we hypothesise that different concentrations of defence compounds and/or nutrients in the leaves and stems of shaded compared with unshaded cocoa affect the feeding preference of mirids. The impact of environmental factors that are modulated by shade, i.e. temperature and light on defence compounds and nutrients were studied through a combination of controlled environment and field studies.

\section{$9 \quad 2.0 \quad$ Materials and methods}

\subsection{Controlled environment experiment}

11 Eight-month-old seedlings (variety: Amelonado) from the International Cocoa Quarantine 12 Centre, at the University of Reading were used. Seedlings selected were those whose new 13 leaves were just about to emerge (flush). Plants were grown in pots (volume $800 \mathrm{ml}$ ) and the 14 potting medium used was an inert mixture of sand, gravel and vermiculite (1:2:2 v:v). They were fed daily with a modified Long Ashton nutrient solution developed for cocoa (End, 1990) with $\mathrm{pH}$ maintained between 5.5 and 5.7 and an electrical conductivity of $2 \mathrm{mS}$. Two walk-in growth chambers were used (dimensions, $3.2 \mathrm{~m}$ long $2.5 \mathrm{~m}$ wide and $1.8 \mathrm{~m}$ high; Fitotron WEISS Gallenkamp, Loughborough, UK). The chambers were set to provide two different day temperatures $\left(30^{\circ} \mathrm{C}\right.$ or $25^{\circ} \mathrm{C}$ day $\left.\pm 0.5^{\circ} \mathrm{C}\right)$ with a common night temperature $\left(22^{\circ} \mathrm{C} \pm 0.5^{\circ} \mathrm{C}\right)$ and a 12 -hour day length to mimic tropical daylength. Each chamber was subdivided into sections to give three different light intensities: $541 \mu \mathrm{mol} \mathrm{m} \mathrm{m}^{-2} \mathrm{~s}^{-1} ; 365 \mu \mathrm{mol} \mathrm{m} \mathrm{s}^{-2}$ 1; and at $181 \mu \mathrm{mol} \mathrm{m} \mathrm{m}^{-2} \mathrm{~s}^{-1}$ photosynthetically active radiation (PAR). Light was provided by fluorescent lamps (MASTER/TL/D/Reflex-58W/840/1SL, Philips) and their intensities were adjusted with a dimmer switch. PAR in each treatment was measured with a LI-COR quantum sensor (LI-191SA; LI-COR, Lincoln, NE 68504, USA) attached to a quantum flux meter (Skye Instruments, Llandrindod Wells).

PAR was measured periodically, to note any changes incident on the plants as they grew taller; values recorded on day 30 were as follows: $550 \mu \mathrm{mol} \mathrm{m} \mathrm{m}^{-2} ; 380 \mu \mathrm{mol} \mathrm{m}^{-2} \mathrm{~s}^{-1}$ and 185 $\mu \mathrm{mol} \mathrm{m} \mathrm{m}^{-2} \mathrm{~s}^{-1}$. Even though plants grew taller as the experiment progressed, the resultant increases in PAR at the shoot apex were relatively small. The experiment was carried out for 50 days in a split plot design with temperature as the main plot and light intensity as subplots 
1 with 5 plants in each treatment. The last six fully expanded leaves and stem cuttings were removed from plants from all treatments after day 50 and kept at $-20{ }^{\circ} \mathrm{C}$ until required for analysis. These samples were later ground in liquid nitrogen and stored at $-80{ }^{\circ} \mathrm{C}$ for subsequent analysis. Tissue concentrations of total phenolics, nitrogen and carbohydrates were determined on three replicate stem and leaf samples under each light and temperature treatment.

\section{$7 \quad 2.2 \quad$ Field experiment}

8 An experiment to study the effect of solar radiation and temperature on the nutrient and total

9 phenolic concentration in cocoa stems and leaves was carried out in the field at the Cocoa 10 Research Institute of Ghana (CRIG), Akim-Tafo (latitude $06^{\circ} 13^{\prime} \mathrm{N}$, longitude $0^{\circ} 22^{\prime} \mathrm{W}$ ), in 11 the Eastern Region of Ghana. The cocoa clones used were: CATIE 1000, IMC 67 and T 12 85/799, originally sourced from the International Cocoa Quarantine Centre, University of 13 Reading, UK. Eight-month-old clonal plants in pots containing loamy soil were transplanted 14 into field plots at a spacing of $2 \mathrm{~m} \times 2 \mathrm{~m}$ in shaded and unshaded treatments with 5 replicate 15 plants per clone per treatment. Shade was provided by shade cloths and plants were watered 16 daily in the mornings at 8:00am. Plants were maintained for 6 months after which stem 17 cuttings and the last six fully expanded leaves were sampled for nitrogen, soluble 18 carbohydrates and total phenolic concentration. Three replicates of stem cuttings and leaf samples were taken from each treatment.

Measurements of light quantity and quality were taken between the hours of 11:00am and 12:00 noon under the shaded and unshaded conditions over 5 days and averaged. A light meter (Skye Instruments, Llandrindod Wells) fitted with a LI-COR light sensor was used to measure PAR, whilst UV radiation (UVA \& UVB) was measured with a UV meter (Solartech Inc. Solar meter model 5.7, UK). Temperature and relative humidity measurements were recorded with miniature data loggers (Gemini Tiny Tags, UK) placed in Stevenson screens, set to $\log$ at 30 minutes intervals, for 5 days and averaged. Total phenolics, nitrogen and carbohydrates were determined in leaf and stem samples. The experiment was an un-replicated split plot design with shade regime as main plots and cocoa clones as sub-plots in replicates of five. The field experiment was carried out from February to July, 2012 and the whole experiment was repeated between August 2012 and January 2013. 


\section{Total phenolics extraction and analysis}

2 Total phenolic concentration of samples taken from both the controlled environment and field

3 studies were determined using a method described by Singleton and Rossi (1965), using

4 Folin-Ciocalteu as the reactive reagent on samples ground while frozen under liquid nitrogen.

5 Preparation of the calibration curve for total phenolic concentration determination was

6 carried out using gallic acid at a concentration of $0.5 \mathrm{~g} / 500 \mathrm{ml}$ and diluted serially 8 times. The

7 total phenolic concentration was expressed as Gallic acid equivalents (GAE).

\section{$8 \quad$ Nitrogen analysis}

9 Nitrogen concentration of dried ground samples from the controlled environment studies was

10 determined by a micro-Kjeldhal method. This analysis was carried out by the Farm Advisory

11 Services Team (FAST), Faversham, UK. Samples were subjected to sulphuric acid/selenium 12 digest followed by dilution and analysis through a Foss Fiastar 5000 Flow Analysis Injection 13 analyser. The digested solution was made highly alkaline by merging with a sodium 14 hydroxide stream, which releases ammonia gas that permeates a gas permeable membrane 15 and into an indicator stream. The intensity of the colour produced was read photometrically at $16590 \mathrm{~nm}$ and the concentration of ammonium nitrogen was read against a calibration curve.

17 Determination of nitrogen concentration for field samples in Ghana was carried out using a modified form of the Kjeldhal method as described by Bremner and Mulvaney (1982).

\section{Carbohydrate analysis}

20 The carbohydrate concentration of ground stem and leaf samples taken from the controlled environment experiment was determined using the method described by Yemm and Willis (1954) with anthrone as a reagent. The green colour produced when carbohydrates are heated with anthrone in acid solution is the basis for this test. The carbohydrate concentration in field samples was determined by the method described by Dubois et al. (1956). This method is based on the reaction between simple sugars and phenol and concentrated sulphuric acid, which generates a yellow-orange colour. Different methods for carbohydrate extraction had to be used for the controlled environment and field experiments as the same equipment was not available in both places. Thus, we do not compare absolute carbohydrate values between the two sets of data. However, de Toledo et al. (2012) demonstrated the different methods measure the same type of carbohydrates and give comparable results. 


\section{$1 \quad 2.3 \quad$ Mirid feeding preference test for cocoa clones (choice test)}

2 Stem cuttings were taken from different clones to evaluate their attractiveness (defined as a combination of attraction and antixenosis) to mirids after exposure to either shaded and unshaded treatments in the field for six months in Ghana using the method described by N' Guessan et al. (2008). Healthy young twigs of each of the three cocoa clones from the shaded and unshaded treatments in the field experiment were cut into $5-\mathrm{cm}$ sections and arranged randomly each time with each piece touching another in Petri dishes forming a hexagon of six sections. Cuttings were selected from plants of the same age and similar size at the midsections with similar circumference. Adult mirids were collected from CRIG plots at Tafo with hybrid cocoa and reared on chupons and pods in an insectary as described by Babin et al. (2008). One $4^{\text {th }}$ instar (nymph which has just developed wing buds) S. singularis mirid nymph of the next generation, starved for 24 hours to the time of screening, was placed in the middle of each Petri dish and the number of feeding lesions on stem cuttings counted and recorded after $24 \mathrm{hrs}$. The test was conducted twice with 8 replicates on each occasion making a total of 16 cuttings per clone * shade treatment. Petri dishes were placed on insectary benches to obtain uniform distribution of light on test materials at an average room temperature of $25^{\circ} \mathrm{C}$.

\subsection{Statistical analysis}

The differences in the concentration of nitrogen, carbohydrate and phenolics in samples as a result of the different treatments under both controlled and field conditions were determined using an ANOVA. In the mirid feeding preference tests, the impact of shaded and unshaded treatments as well as the different cocoa clones on mirid feeding was also analysed by means of ANOVA. For the field experiment, the analysis was performed on the combined data of the two repeated experiments since initial analysis showed no significant differences in the repeated experiments for phenolics, nitrogen, carbohydrate concentrations and mirid feeding preference. Data was analysed with GenStat version 11.

\subsection{Results}

29

\subsection{Controlled environment}

\section{$31 \quad$ 4.1.1 Total phenolics}

There was a non-significant trend of a reduction in phenolic concentration in stems with an increase in PAR $(\mathrm{P}=0.06)$ or temperature $(\mathrm{P}=0.79)$. There was also no significant effect of 
1 light $(\mathrm{P}=0.9)$ or temperature $(\mathrm{P}=0.64)$ on the total phenolic concentration in leaf samples 2 measured (data not shown).

3

\section{$4 \quad$ 4.1.2 Nitrogen}

5 The nitrogen concentration of leaves was significantly greater in plants grown under higher 6 light intensity $(\mathrm{P}=0.003)$ (Fig. 1 A). A significant interaction of light and temperature was 7 observed on percentage nitrogen in stems ( $\mathrm{P}=0.05)$ (Fig. 1 B). Stem nitrogen concentration of 8 plants grown at $30^{\circ} \mathrm{C}$ increased with increasing light intensity. However, this trend was not 9 observed at $25^{\circ} \mathrm{C}$. As with leaves, stems under the highest light level also had the greatest 10 percentage nitrogen $(\mathrm{P}=0.04)$ while temperature had no significant effect $(\mathrm{P}=0.28)$.

11

12

13

14

15

16

17

\section{Figure 1 here}

\subsubsection{Soluble carbohydrates}

A significant interaction of light and temperature on soluble carbohydrate concentration of cocoa leaves was observed $(\mathrm{P}=0.04)$ such that an effect of temperature $(\mathrm{P}=0.04)$ (Fig. $2 \mathrm{~A})$ was only observed at a PAR of $365 \mu \mathrm{mol} \mathrm{m} \mathrm{m}^{-2} \mathrm{~s}^{-1}$ (where carbohydrate concentration was higher at $25^{\circ} \mathrm{C}$ ). There was also a significant interaction of light and temperature on the carbohydrate concentration of stems $(\mathrm{P}=0.03)$ whereby carbohydrate concentration was higher at $30^{\circ} \mathrm{C}$ at PAR levels of 181 and $365 \mu \mathrm{mol} \mathrm{m}^{-2} \mathrm{~s}^{-1}$ but no significant differences between temperatures were evident at the highest PAR (Fig. 2 B).

\section{Figure 2 here}




\section{$1 \quad 4.2$ Field experiment}

\subsection{Microenvironment}

3 UVA radiation was significantly higher in the unshaded treatment (mean $=0.40 \mathrm{mw} \mathrm{cm}^{-2}$ ) 4 relative to shade treatment $\left(\right.$ mean $\left.=2.4 \mathrm{mw} \mathrm{cm}^{-2}\right)(\mathrm{P}<0.001 ; \mathrm{Lsd}=0.18)$. UVB radiation was 5 also significantly higher under the unshaded treatment (mean $=289.67 \mu \mathrm{w} \mathrm{cm}^{-2}$ ) than the 6 shaded treatment (mean $\left.=27.33 \mu \mathrm{w} \mathrm{cm}^{-2}\right)(\mathrm{P}<0.001 ; \mathrm{Lsd}=3.5)$. PAR (between 11:00 and 7 12:00) measured under unshaded conditions was significantly greater (mean $=1767 \mu \mathrm{mol} \mathrm{m}{ }^{-2}$ $\left.8 \mathrm{~s}^{-1}\right)$ compared with the shade treatment $\left(180 \mu \mathrm{mol} \mathrm{m}^{-2} \mathrm{~s}^{-1}\right)(\mathrm{P}<0.001 ; \mathrm{Lsd}=122.7)$. Day time mean temperature under unshaded conditions (mean $=32{ }^{\circ} \mathrm{C}$ ) was significantly greater than that measured under shade $\left(\right.$ mean $\left.=25^{\circ} \mathrm{C}\right)(\mathrm{P}=0.01 ; \mathrm{Lsd}=4.14)$, whilst there was no significant difference in relative humidity measured in unshaded (mean=57\%) compared with the shaded treatment $(62 \%)(\mathrm{P}=0.08 ; \mathrm{Lsd}=6)$.

\subsubsection{Total phenolics}

A significant interaction between clone and shade treatments was observed in the concentration of total phenolics in leaves $(\mathrm{P}=0.03)$. For all three cocoa clones, the concentration of phenolics was higher under non-shaded conditions but the magnitude of the difference was not consistent across clones (Fig. 3A). The difference between the phenolic concentration of unshaded and shaded IMC 67 was greater than $18 \mathrm{mg} \mathrm{g}^{-1}$ while for CATIE 1000 and T85/799, the differences were approximately $12 \mathrm{mg} / \mathrm{g}$ and $7 \mathrm{mg} / \mathrm{g}$, respectively. Phenolic concentration in stems was also influenced by the shade treatments $(\mathrm{P}=0.04)$ (Fig. 3 B). There was a significant effect of shade on the phenolic concentration of CATIE 1000 (higher under no shade conditions) but not on the other two clones. In all, the phenolic concentration of leaves (mean $=89 \mathrm{mg} / \mathrm{g}$ ) was significantly greater than that in stems (42 $\mathrm{mg} / \mathrm{g})(\mathrm{P}<0.001 ; \mathrm{Lsd}=8.6)$.

\section{Figure 3 here}

\subsubsection{Nitrogen}

There was a significant interaction between shade treatments and clone on the nitrogen concentration of stems $(\mathrm{P}=0.01)$. The effect of shade was significant only for CATIE 1000 and IMC 67. However, the direction of response was inconsistent as under the shaded 
1 condition the nitrogen concentration of CATIE 1000 in stems was significantly greater than in unshaded trees while the reverse was observed for IMC 67 (Fig. 4).

\section{Figure 4 here}

\section{$5 \quad$ 4.2.3 Soluble carbohydrates}

6 Carbohydrate concentration of leaves was significantly influenced by clone $(\mathrm{P}<0.001)$ as well 7 as by shade treatments $(\mathrm{P}<0.001)$ (Fig. 5A). Carbohydrate concentration was greater in unshaded conditions and highest for IMC $67(25 \mathrm{mg} / \mathrm{g})$. There was no significant interaction between clone type and shade treatments. It can be seen from Figure $5 \mathrm{~B}$ that there is a significant interaction between shade treatments and clones on carbohydrate concentration in stems $(\mathrm{P}=0.01)$. In all cases, carbohydrate concentration was greater under the unshaded treatment but the magnitude of the difference was greatest for CATIE 1000.

\section{Figure 5 here}

\subsubsection{Mirid preference test for cocoa clones}

Stem cuttings from unshaded cocoa clones had significantly $(\mathrm{P}=0.003)$ more mirid feeding lesions after $24 \mathrm{hrs}$ exposure to previously starved $4^{\text {th }}$ instar mirids compared to stem cuttings from shaded cocoa clones (Fig. 6). The effect of shade on mirid feeding preference was greater for IMC 67 and T 85/799 than for CATIE 1000. There was however no significant effect of clone on mirid feeding preference.

Figure 6 here

\section{$22 \quad 5.0 \quad$ Discussion}

23 Most phytophagous insects have a narrow range of host plants on which they feed. This host range is often limited by the presence or absence of chemical (secondary metabolites) or physical feeding stimulants or deterrents. Such chemical stimulants or deterrents are usually complex in nature and may have more than one function depending on the plant species in question (Close and McArthur, 2002, Lattanzio et al., 2009). Plant phenolic compounds, an example of such secondary metabolites, are found mainly in the epidermis and its appendages and may act as the first line of defence absorbing the harmful UV region of the light spectrum

30 (Caldwell et al., 1983, Grammatikopoulos et al., 1999, van Emden, 1966). However, phenolic compounds may have some other important functions. They are reported to function as antifungal agents and due to their bitter taste, are considered as potential feeding deterrents to 
1 insect herbivores (Matern and Kneusel, 1988, Bernays et al., 1989, Berenbaum, 1995,

2 Haukioja et al., 2002). On the other hand, nutrients such as nitrogen and carbohydrates have 3 been reported to enhance insect growth and development (van Emden, 1966, Waring and 4 Cobb, 1992, Entwistle, 1985). This study sought to clarify the effect of light and temperature on plant nutrients and phenolic compounds in cocoa, thereby potentially providing some understanding as to why mirids prefer unshaded to shaded cocoa. Mirid numbers increase under shaded cocoa when there is a break in the canopy permitting more light into the crop canopy (Padi and Owusu, 1998, Babin et al., 2010).

Differences in phenolic concentration of leaves and stems observed under different light and temperature treatments under controlled environment and shaded and unshaded cocoa in the field experiment suggest that light and temperature influences nutrients and phenolic concentrations in leaves and stems of cocoa. Under controlled conditions, there was a trend of increasing concentration of total phenolic compounds in young cocoa stems as PAR levels decreased. This result was different from that observed in the field where significantly more phenolic compounds were measured in unshaded compared to shaded cocoa. The difference in the quality and quantity of light that plants were exposed to could explain the difference in results obtained between controlled and field experiments. In the field, plants were subjected to a broader spectrum of light and high levels of UVA and UVB were measured, which are reported to influence the phenolic synthesis pathway in plants (Hatcher and Paul, 1994, Zavala et al., 2001). However, UV light was absent in fluorescent tubes used in providing light under the controlled environment experiment. As mirids preferred feeding on twigs kept under unshaded conditions with relatively high phenolic concentrations as observed in the mirid preference tests, high phenolic concentration of stems however, does not appear to be a major deterrent to mirid feeding. These results suggest that, whilst phenolic compounds in cocoa could provide protection against photo-damage from harmful rays from the sun they do not necessarily act as defence against insect herbivory. This is in agreement with the report of Close and McArthur (2002) as they concluded that plant phenolic compounds do not necessarily provide defence against insect herbivory, but rather provide protection from photo-damage. However, the results are not consistent with the report of Dudt and Shure (1994) that slow growing dogwood under shade produce more phenolics to act as feeding deterrents as they are unable to grow rapidly enough to recover from pest damage. Hatcher and Paul (1994) highlighted the risk in attributing changes in insect feeding preference only 
1 to the effect of phenolic compounds and other plant secondary metabolites. It would appear

2 from our results that, for cocoa, the presence of phenolics are not a major deterrent to insect

3 feeding. Another hypothesis may be that mirids have evolved to be able to metabolize

4 phenolic compounds.

5

6

The observation of higher levels of nitrogen in the controlled environment study with increased light intensity was not experienced in the field. Moreover, the direction of response to light conditions differed between cocoa genotypes. Entwistle (1972) and Anikwe et al. (2009) have reported enhanced mirid feeding and development under high levels of nitrogen. White et al. (1984), Ohmart et al. (1985) and Myers (1981) also reported enhanced insect (Glycaspis spp.) growth and activity under conditions that increased the amount of nitrogen available to insects in their food. Even though mirids preferred twigs obtained from unshaded conditions in the choice test, nitrogen level was only higher for one clone (IMC 67) under such conditions. Thus, the results did not produce conclusive evidence of an effect of nitrogen concentration of cocoa stem tissues on mirid feeding preference. A reduction in nitrogen in some plant species is related to an increase in carbon-based phenolic compounds (Kytö et al., 1996). Keski-Saari and Julkunen-Tiitto (2003) demonstrated that the concentration of phenolics was higher in different parts of juvenile mountain birch plants (Betula pubescens ssp. czerepanovii (N.I. Orlova) Hämet-Ahti) at lower levels of nitrogen than at moderate nitrogen level. However, in the present study the effect of the variation in cocoa nitrogen concentrations on the level of phenolics was not consistent across clones.

Carbohydrate concentrations of leaves and stems in the field were higher under unshaded compared with shaded conditions. This could be attributed to enhanced photosynthetic activity and hence greater carbohydrate production under high light intensities. High concentrations of carbohydrates in young shoots/stems under no shade may be a reason why mirids prefer unshaded to shaded cocoa. The tender nature of such young stems with high moisture content may also be a reason why mirids prefer them to older shoots/stems. The fact that mirids preferentially fed on cocoa grown under unshaded conditions with higher carbohydrate concentrations suggests that nutrient concentration could be an important determinant of mirid feeding activity on cocoa. As there were no significant effect of clone on the number of mirid feeding lesions, the exposure of cocoa plants to different environmental conditions was the critical factor determining mirid feeding preference. The fact that nutrient status appears to impact on mirid feeding preference could explain 
1 inconsistencies in reporting of which cocoa clones are resistant to mirid damage across West

2 Africa. Mirid resistant clones in one country have been reported to be susceptible in another

3 (N'Guessan et al., 2008, Anikwe et al., 2009). The effects of prevailing environmental

4 conditions and hence stem carbohydrate levels are usually not considered when clones are

5 tested. However, our results show that, in some cases, environmental conditions may override

6 inherent genotypic factors that might incur pest resistance. Therefore, it is important that

7 when screening for mirid resistance the cocoa clones should be grown and tested under a 8 range of uniform conditions.

10 Conclusion

11 Light intensities and temperature both had an impact on nitrogen and carbohydrate concentrations in cocoa tissues, whilst UV radiation was associated with an increase in phenolics. Since mirids preferentially fed on cocoa stems that were higher in phenolics and nutrients, it is concluded that phenolics do not deter mirid feeding but that higher nutrient concentration, specifically carbohydrates, provides a plausible explanation for preferential 16 feeding.

\section{Acknowledgment}

19 The authors would like to express their gratitude to Mondelez Inc. and BBSRC-Dorothy 20 Hodgkin Postgraduate Award for sponsoring this study as well as CRIG management for 21 logistical support. We are also grateful to staff of the Entomology, Physiology-Biochemistry and Soil Science divisions of CRIG for their help in collecting data for the study, notably Dickson Ampadu, Abraham Sowah, Ebenezer Obeng Mintah, Godson Fiakegbe, Rafiatu Kotie and Enoch Chawudzi. This paper is published with the kind permission of the Executive Director of CRIG (CRIG/03/2020/009/006). 


\section{References}

Acheampong, K., Hadley, P \& Daymond, A.J. (2013). Photosynthetic activity and early growth of four cacao genotypes as influenced by different shade regimes under West African dry and wet season condition. Experimental Agriculture, 49, 31-42.

Acheampong, K. (2010). A physiological study on the field establishment of cacao clones through the improvement of agro-ecological conditions. PhD thesis, University of Reading, Reading.

Ahenkorah, Y. \& Akrofi, G. S. (1971). Recent results of fertilizer experiments on shaded cocoa (Theobroma cacao L.) in Ghana. Proceedings of the 3rd International Cocoa Research Conference, pp 65-78. Accra, Ghana.

Ahenkorah, Y., Akrofi, G. S. \& Adri, A. K. (1974). The end of the first cocoa shade and manurial experiment at the Cocoa Research Institute of Ghana. Journal of Horticultural Science, 49, 43-51.

Altieri, M. A. \& Nicholls, C. I. (2003). Soil fertility management and insect pests: harmonizing soil and plant health in agroecosystems. Soil and Tillage Research, 72, 203-211.

Anikwe, J. C. (2010). Feeding preference and morphometrics of Sahlbergella singularis (Hemiptera: Miridae) on cocoa pod at different stages of physiological development. Academic Journal of Entomology, 3, 39-44.

Anikwe, J. C., Omoloye, A. A., Aikpokpodion, P. O., Okelana, F. A. \& Eskes, A. B. (2009). Evaluation of resistance in selected cocoa genotypes to the brown cocoa mirid, Sahlbergella singularis Haglund in Nigeria. Crop Protection, 28, 350-355.

Awudzi, G. K., Ackonor, J. B., Cudjoe, A. R., Dwomoh, E. A. \& Sarfo, J. E. (2009). Manual for cocoa insect pests, symptoms of their damage and methods of their control, NewTafo, Akim, Cocoa Research Institute of Ghana.

Babin, R., Bisseleua, D. H. B., Dibog, L. \& Lumaret, J. P. (2008). Rearing method and lifetable data for the cocoa mirid bug Sahlbergella singularis Haglund (Hemiptera: Miridae). Journal of Applied Entomology, 132, 366-374.

Babin, R., Ten Hoopen, G. M., Cilas, C., Enjalric, F., Gendre, P. \& Lumaret, J.-P. (2010). Impact of shade on the spatial distribution of Sahlbergella singularis in traditional cocoa agroforests. Agricultural and Forest Entomology, 12, 69-79.

Berenbaum, M. R. (1995). The chemistry of defense: Theory and practice. In: Meinwald, J. \& Eisner, T. (eds.) Chemical Ecology: The Chemistry of Biotic Interaction. Washington, DC: National Academy of Sciences of the United States of America.

Bernays, E. A., Cooper Driver, G. \& Bilgener, M. (1989). Herbivores And Plant Tannins. In: Begon, M., Fitter, A. H., Ford, E. D. \& Macfadyen, A. (eds.) Advances in Ecological Research. London: Academic Press.

Bigger, M. (1981). Observations on the insect fauna of shaded and unshaded Amelonado cocoa. Bulletin of Entomological Research, 71, 107-119.

Bos, M. M., Steffan-Dewenter, I. \& Tscharntke, T. (2007). Shade tree management affects fruit abortion, insect pests and pathogens of cacao. Agriculture, Ecosystems \& Environment, 120, 201-205.

Bremner, J. M. \& Mulvaney, C. S. (1982). Total Nitrogen. In: Page, A. L., Miller, R. H. \& Keeney, D. R. (eds.) Methods of Soil Analysis. Part 2. Chemical and microbiological properties. American Society of Agronomy and Soil Science Society of America.: Madison Wisconsin Inc. 593-624.

Bryant, J. P., Chapin, F. S., Iii \& Klein, D. R. (1983). Carbon/Nutrient Balance of Boreal Plants in Relation to Vertebrate Herbivory. Oikos, 40, 357-368. 
Caldwell, M., Robberecht, R. \& Flint, S. (1983). Internal filters: Prospects for UVacclimation in higher plants. Physiologia Plantarum, 58, 445-450.

Campbell, C. A. M. (1984). The influence of overhead shade and fertilizers on the Homoptera of mature Upper-Amazon cocoa trees in Ghana. Bulletin of Entomological Research, 74, 163-174.

Close, D. C. \& Mcarthur, C. (2002). Rethinking the role of many plant phenolics - protection from photodamage not herbivores? Oikos, 99, 166-172.

Dubois, M., Gilles, K. A., Hamilton, J. K., Reber, P. A. \& Smith, F. (1956). Calorimetric method for determination of sugars and related substances. Analytical Chemistry, 28, 350-356.

Dudt, J. F. \& Shure, D. J. (1994). The influence of light and nutrients on foliar phenolics and insect herbivory. Ecology, 75, 86-98.

Duffey, S. S. \& Stout, M. J. (1996). Antinutritive and toxic components of plant defense against insects. Archives of Insect Biochemistry and Physiology, 32, 3-37.

End, M. J. 1990. A study of the effects of the photo-thermal environment on fruit and seed growth and development in Theobroma cacao L., The University of Reading.

Entwistle, P. F. (1972). Pests of Cocoa, Longman Group Ltd. 221-311.

Entwistle, P. F. (1985). Insects and cocoa. In: Wood, G. A. R. \& Lass, R. A. (eds.) Cocoa, pp. 366-409. 4th ed.: Longman Group Limited.

Grammatikopoulos, G., Petropoulou, Y. \& Manetas, Y. (1999). Site-dependent differences in transmittance and UV-B-absorbing capacity of isolated leaf epidermes and mesophyll in Urginea maritima (L.) Baker. Journal of Experimental Botany, 50, 517-521.

Halkier, B. A. \& Du, L. (1997). The biosynthesis of glucosinolates. Trends in Plant Science, 2, 425-431.

Hatcher, P. E. \& Paul, N. D. (1994). The effect of elevated UV-B radiation on herbivory of pea by Autographa gamma. Entomologia Experimentalis et Applicata, 71, 227-233.

Haukioja, E., Ossipov, V. \& Lempa, K. (2002). Interactive effects of leaf maturation and phenolics on consumption and growth of a geometrid moth. Entomologia Experimentalis et Applicata, 104, 125-136.

Keski-Saari, S. \& Julkunen-Tiitto, R. (2003). Resource allocation in different parts of juvenile mountain birch plants: effect of nitrogen supply on seedling phenolics and growth. Physiologia Plantarum, 118, 114-126.

Kytö, M., Niemelä, P. \& Larsson, S. (1996). Insects on trees: Population and individual response to fertilization. Oikos, 75, 148-159.

Lattanzio, V., Kroon, P. A., Quideau, S. \& Treutter, D. (2009). Plant Phenolics - Secondary Metabolites with Diverse Functions, Wiley-Blackwell.

Lee, K. P., Raubenheimer, D., Behmer, S. T. \& Simpson, S. J. (2003). A correlation between macronutrient balancing and insect host-plant range: evidence from the specialist caterpillar Spodoptera exempta (Walker). Journal of Insect Physiology, 49, 11611171.

Matern, U. \& Kneusel, R. E. (1988). Phenolic compounds in plant disease resistance. Phytoparasitica, 16, 153-170.

Myers, J. H. \& Post, B. J. (1981). Plant nitrogen and fluctuations of insect populations: A test with the Cinnabar Moth: Tansy Ragwort System. Oecologia, 48, 151-156.

N'guessan, K. F., N'goran, J. A. K. \& Eskes, A. B. (2008). Resistance of cacao ( Theobroma cacao L.) to Sahlbergella singularis (Hemiptera: Miridae): investigation of antixenosis, antibiosis and tolerance. International Journal of Tropical Insect Science, 28, 201-210. 
Ohmart, C. P., Stewart, L. G., Thomas, J. R. \& Steward, L. G. (1985). Effects of food quality, particularly nitrogen concentrations, of Eucalyptus blakelyi foliage on the growth of Paropsis atomaria larvae (Coleoptera: Chrysomelidae). Oecologia, 65, 543-549.

Ossipov, V., Haukioja, E., Ossipova, S., Hanhimäki, S. \& Pihlaja, K. (2001). Phenolic and phenolic-related factors as determinants of suitability of mountain birch leaves to an herbivorous insect. Biochemical Systematics and Ecology, 29, 223-240.

Padi, B. \& Owusu, G. K. (1998). Towards an integrated pest management for sustainable cocoa production in Ghana. Workshop. Panama, Smithsonian Institution, Washington, D.C.

Singleton, V. L. \& Rossi, J. A. (1965). Colorimetry of total phenolics with phosphomolibdicphosphotungstic acid reagents. American Journal of Enology and Viticulture, 16, 144158.

Stotz, H. U., Kroymann, J. \& Mitchell-Olds, T. (1999). Plant-insect interactions. Current Opinion in Plant Biology, 2, 268-272.

Thompson, S. N. \& Hagen, K. S. (1999). Nutrition of entomophagous insects and other arthropods. In: Thomas, S. B., Fisher, T. W., Caltagirone, L. E., Dahlsten, D. L., Gordh, G. \& Huffaker, C. B. (eds.) Handbook of Biological Control. San Diego: Academic Press.

Vagner De Alencar Arnaut De Toledo, Maria Claudia Colla Ruvolo-Takasusuki, Arildo José Braz De Oliveira, Emerson Dechechi Chambó \& Lopes, S. M. S. (2012). Spectrophotometry as a Tool for Dosage Sugars in Nectar of Crops Pollinated by Honeybees. In: Uddin, D. J. (ed.) Macro To Nano Spectroscopy. InTech.

Van Emden, H. F. (1966). Studies on the relationships of insect and plant host. III. A comparison of the reproduction of Brevicoryne brassicae and Myzus persicae (Hemiptera: Aphididae) on Brussels sprout plants supplied with different rates of nitrogen and potassium. Entomologia experimentalis et applicata, 9, 444-460.

Waring, R. H. \& Cobb, N. S. (1992). The impact of plant stress on herbivore population dynamics. In: Bernays, E. (ed.) Insect-plant interactions. CRC Press, Boca Raton,FL.

White, T. C. R. (1984). The abundance of invertebrate herbivores in relation to the availability of nitrogen in stressed food plants. Oecologia, 63, 90-105.

Yemm, E. W. \& Willis, A. J. (1954). The estimation of carbohydrates in plant extracts by anthron. Biochemical Journal, 57, 508-514.

Zavala, J. A., Scopel, A. L. \& Ballaré, C. L. (2001). Effects of ambient UV-B radiation on soybean crops: Impact on leaf herbivory by Anticarsia gemmatalis. Plant Ecology, $156,121-130$. 


\section{Figure legends}

Figure 1: Effect of light and temperature on percentage nitrogen concentration in the leaves (A) and stems (B) of young cocoa. Each bar represents a mean of three replicates.

Figure 2: Effect of PAR and temperature on carbohydrate concentration in cocoa leaves (A) and stems (B). Each bar represents a mean of three replicates. Note difference in scales between A \& B.

9 Figure 3: The interaction of shade treatments and clone on total phenolic concentration of 10 young leaves (A) and stems (B). Note the difference in scales. Each bar represents a mean of 11 six replicates.

12 Figure 4: The interaction of shade and unshaded treatments and clone types on nitrogen 13 concentration of stems. Each bar represents a mean of six replicates.

14 Figure 5: Interaction between shade treatments and clone type on soluble carbohydrate 15 concentration in the leaves (A) and stems (B) of young cocoa. Each bar represents a mean of 16 six replicates.

17 Figure 6: Mirid feeding preference on stem cuttings from shaded and unshaded cocoa. Each 18 bar represents a mean of sixteen replicates. 


\section{Figures}

2

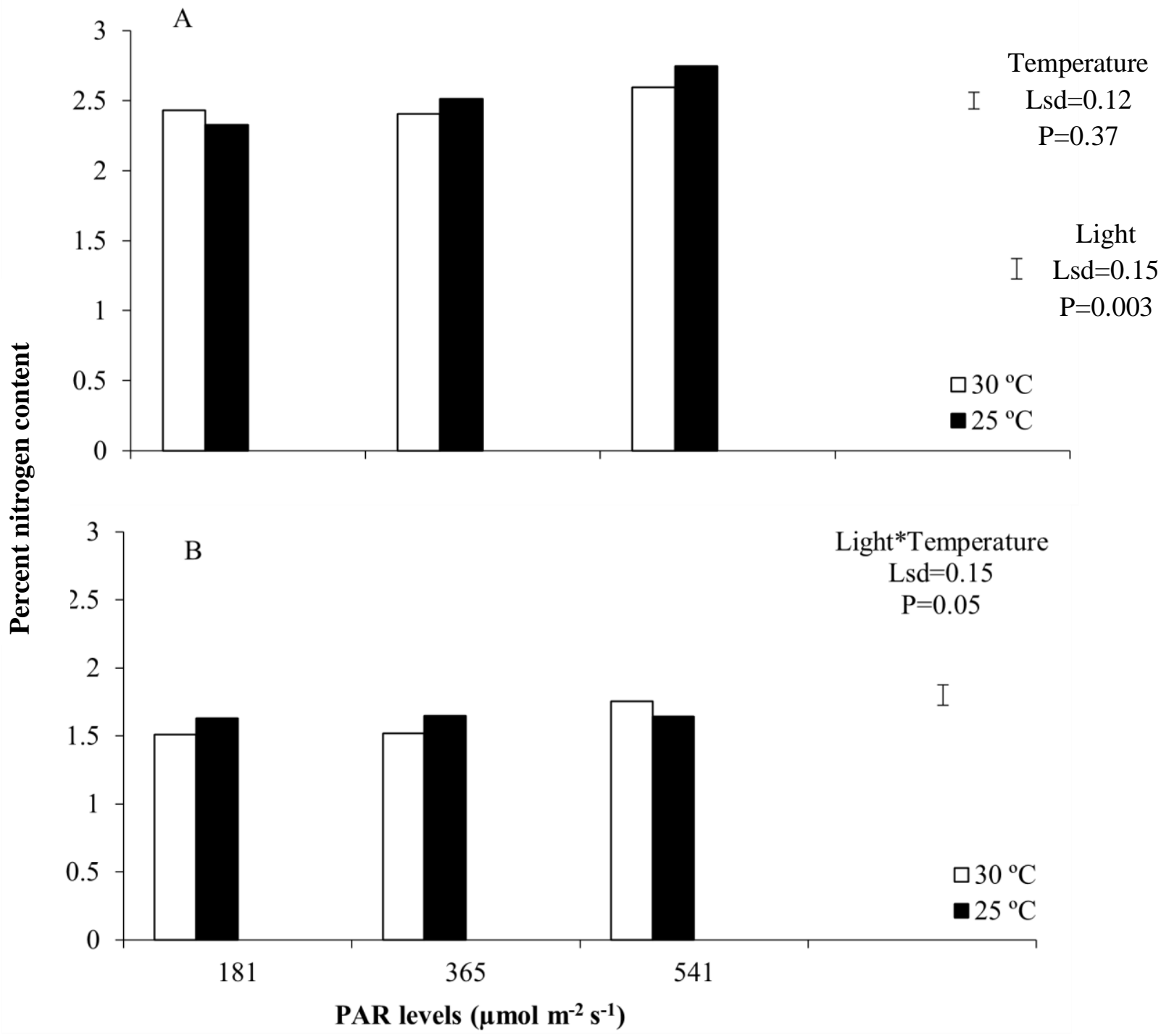

3 Figure 1: Effect of light and temperature on percentage nitrogen concentration in the leaves 4 (A) and stems (B) of young cocoa. Each bar represents a mean of three replicates.

5

6

7

8

9 


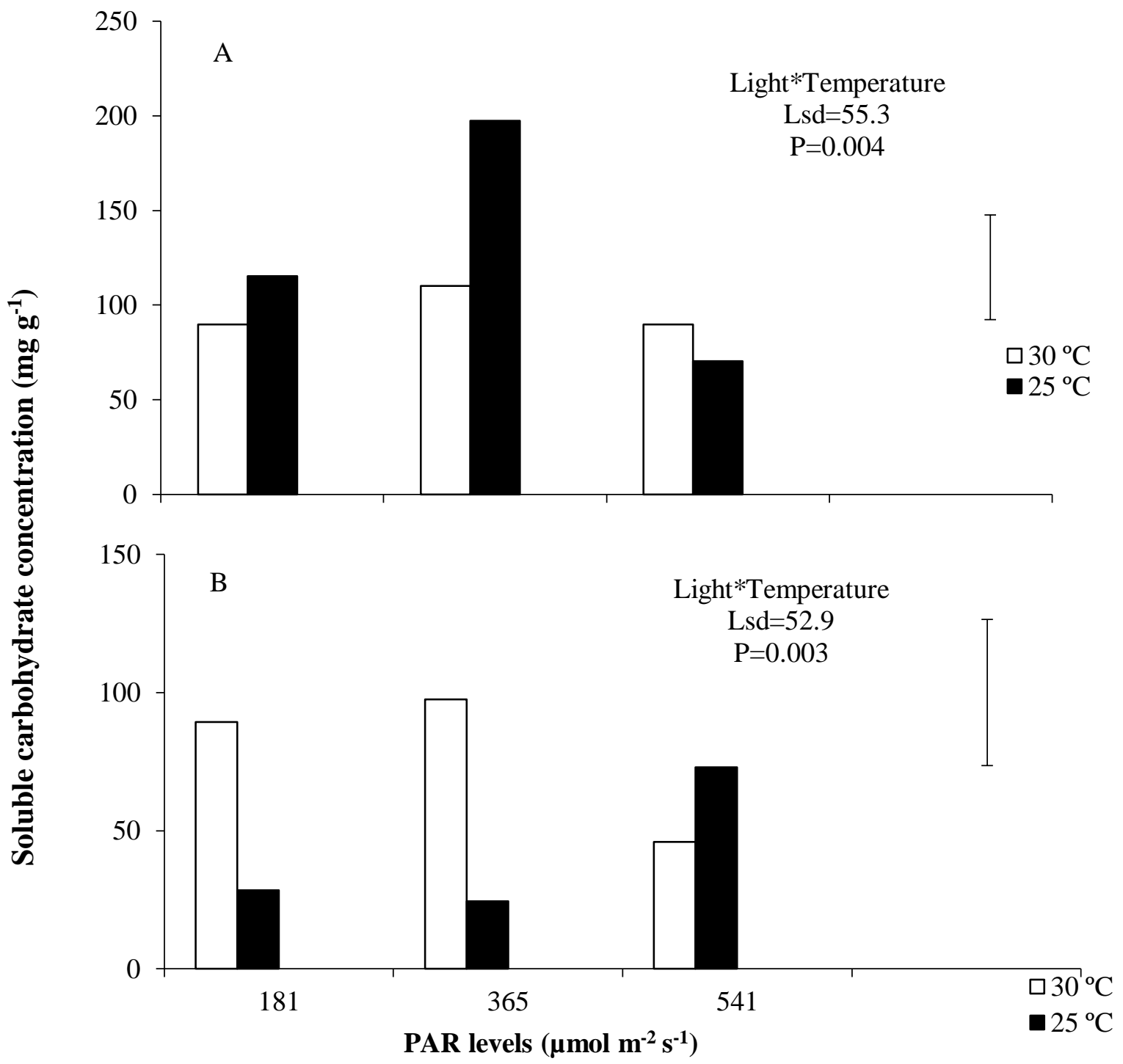

1

2

$3 \quad$ Figure 2: Effect of PAR and temperature on soluble carbohydrate concentration in cocoa 4 leaves (A) and stems (B). Each bar represents a mean of three replicates. Note difference in 5 scales between A \& B.

6

7

8

9 


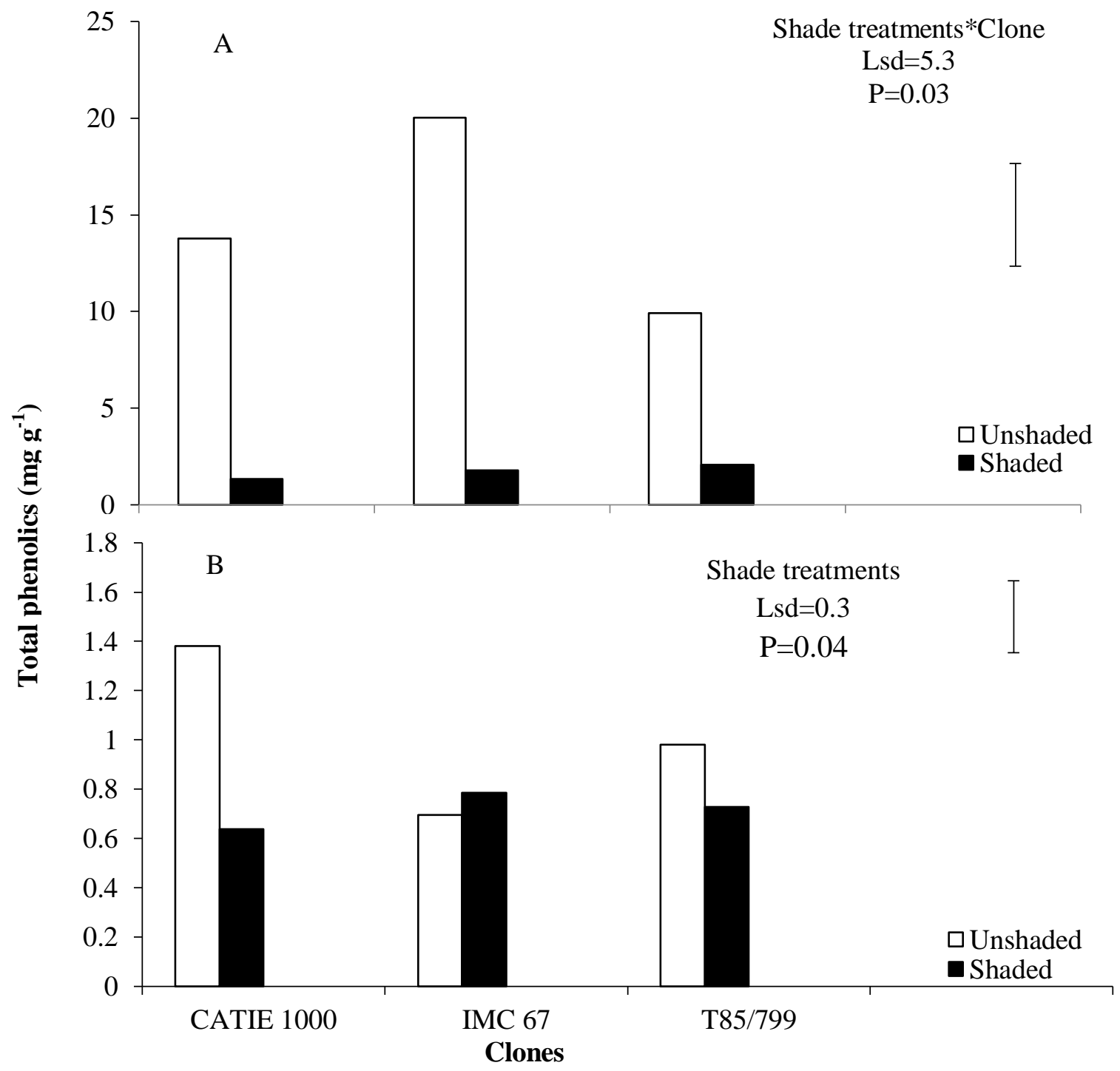

2

3

4

5

6

7

8

9

10

11

12

6

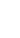

Figure 3: The interaction of shade treatments and clone on total phenolic concentration of young leaves (A) and stems (B). Note the difference in scales. Each bar represents a mean of six replicates. 


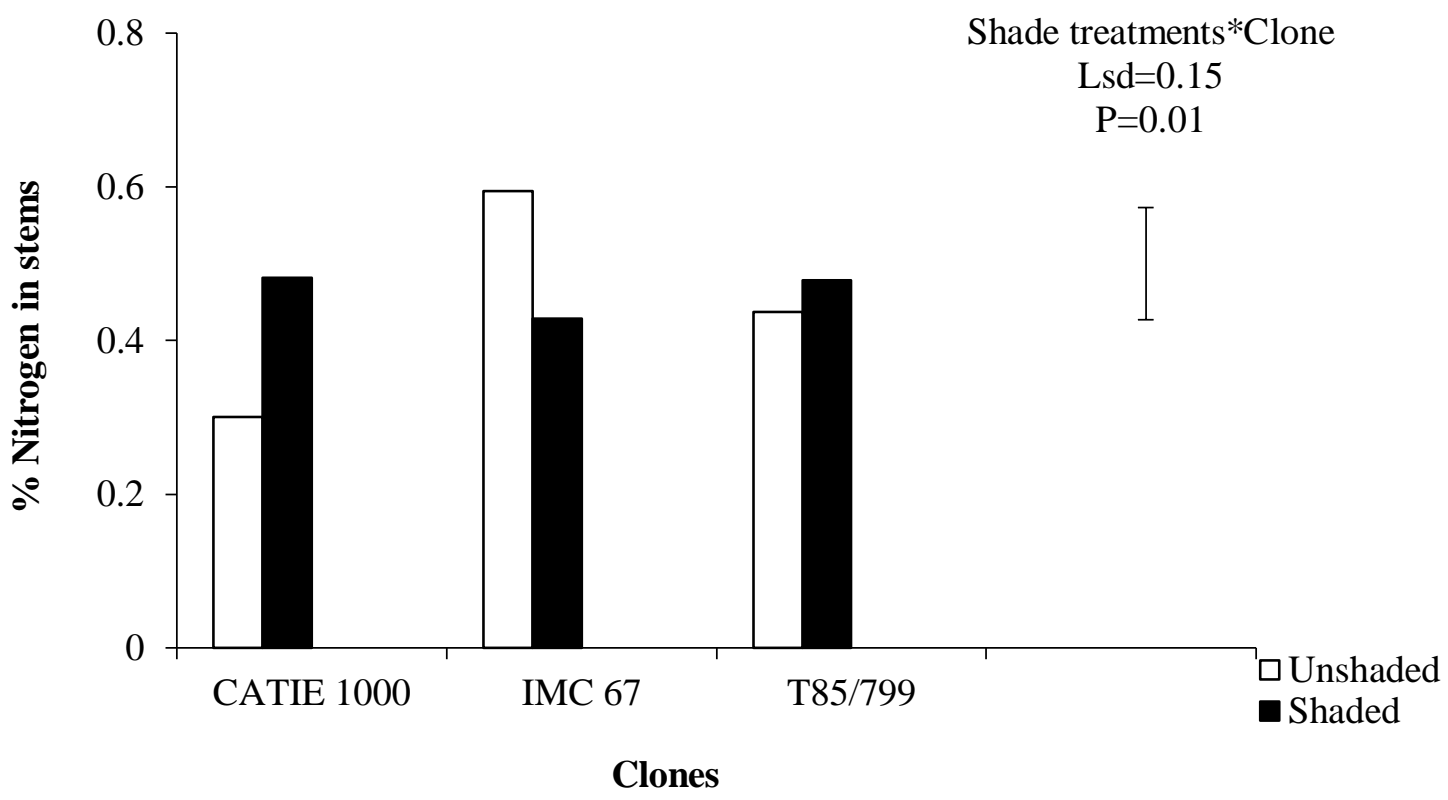

$2 \quad$ Figure 4: The interaction of shade and unshaded treatments and clone types on nitrogen 3 concentration of stems. Each bar represents a mean of six replicates

4

5

6

7

8

9

10

11

12

13

14

15

16

17

18 


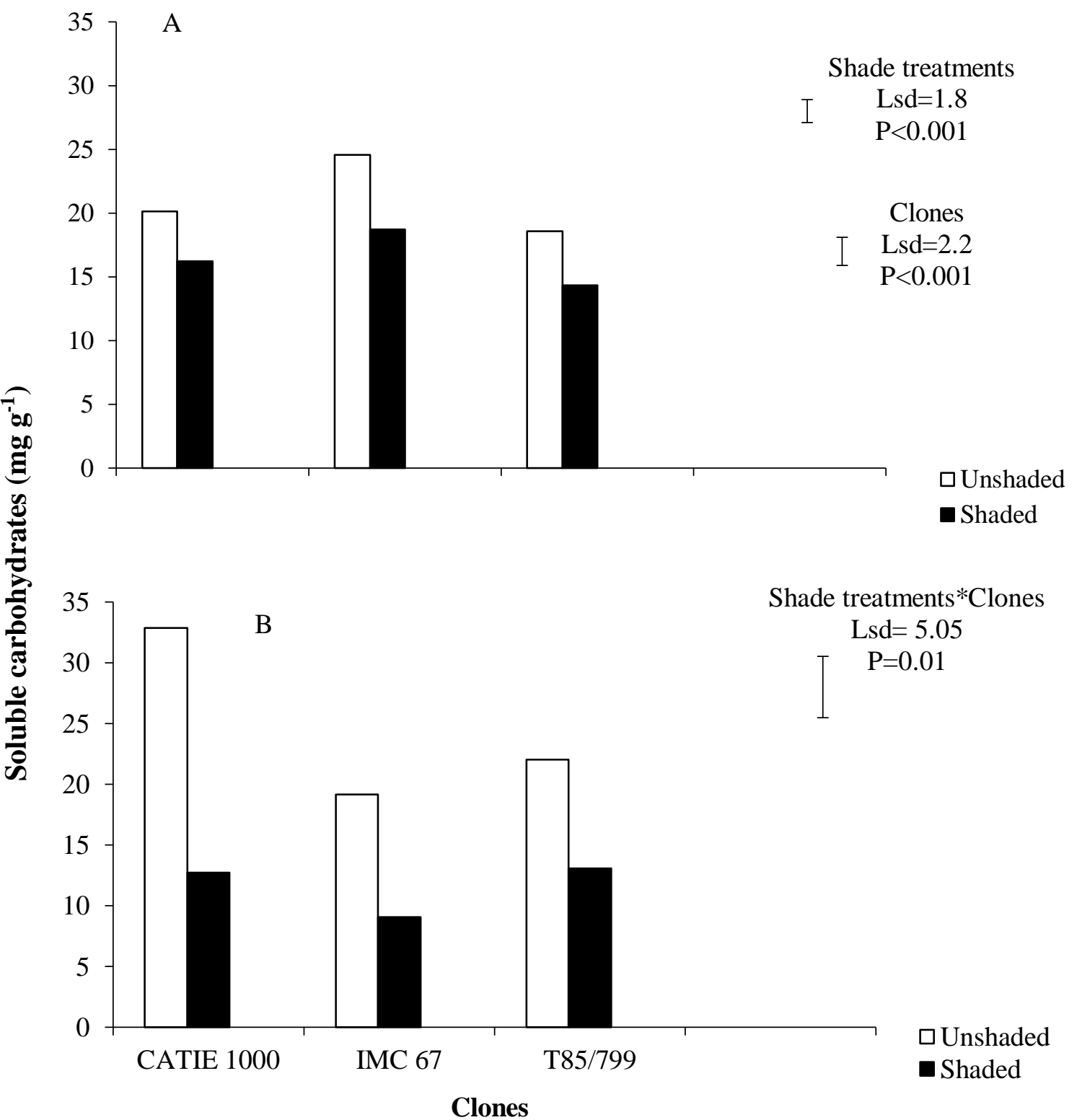

Figure 5: Interaction between shade treatments and clone type on soluble carbohydrate concentration in the leaves (A) and stems (B) of young cocoa. Each bar represents a mean of six replicates.

7

8

9

10

11

12 


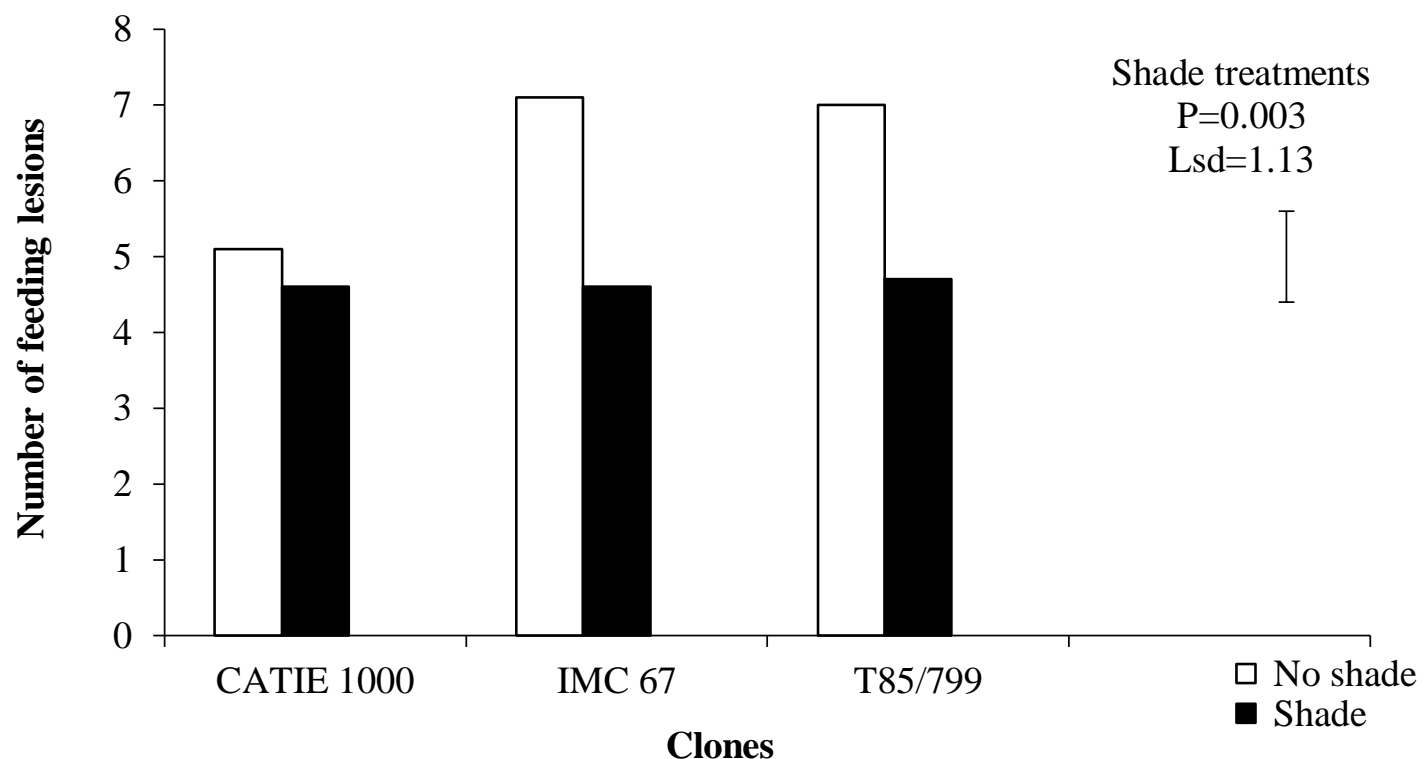

Figure 6: Mirid feeding preference on stem cuttings from shaded and unshaded cocoa. Each bar represents a mean of sixteen replicates. 